\title{
Identification and evaluation of 55 genetic variations in the BRCA1 and the BRCA2 genes of patients from 50 Japanese breast cancer families
}

Received: 29 January 2004/ Accepted: 7 April 2004/Published online: 27 May 2004

(C) The Japan Society of Human Genetics and Springer-Verlag 2004

\begin{abstract}
We sequenced approximately $23 \mathrm{~kb}$ genomic regions containing all the coding exons and their franking introns of two breast cancer susceptibility genes, $B R C A 1$ and $B R C A 2$, of 55 individuals from 50 unrelated Japanese breast cancer families. We identified 55 single-nucleotide polymorphisms (SNPs) (21 in $B R C A 1$ and 34 in $B R C A 2$ ) containing nine pathogenic protein-truncating mutations (four in $B R C A$ land five in $B R C A 2$ from ten patients). Among the remaining 46 SNPs, allele frequencies of 40 were examined in both the breast cancer patients and 28 healthy volunteers with no breast cancer family history by PCRRFLP or by direct DNA sequencing. Twenty-eight SNPs were common and were also found in the healthy volunteers and/or a SNP database. The remaining 18 were rare (allele frequency $<0.05$ ) and were not found in the healthy volunteers and/or the database. The pathogenic significance of these coding SNPs (cSNPs) remains to be clarified. The SNP in-
\end{abstract}

The first two authors contributed equally to this study.

M. Kawahara · M. Sakayori · K. Shiraishi · C. Ishioka ( $ه)$

Department of Clinical Oncology, Institute of Development, Aging and Cancer, Tohoku University, 4-1 Seiryo-machi,

Aoba-ku, Sendai 980-8575, Japan

E-mail: chikashi@idac.tohoku.ac.jp

Tel.: + 81-22-7178547

Fax: + 81-22-7178548

M. Kawahara $\cdot$ S. Takenoshita

Department of Second Surgery,

Fukushima Prefecture College School of Medicine,

Fukushima, Japan

K. Shiraishi $\cdot$ M. Takeda $\cdot$ N. Ohuchi

Division of Surgical Oncology, Tohoku University Graduate

School of Medicine, Sendai, Japan

T. Nomizu

Department of Surgery, Hoshi General Hospital, Koriyama, Japan

R. Abe

Tohoku Familial Tumor Association, Koriyama, Japan formation from this study will be useful in the future genetic testing of both $B R C A 1$ and $B R C A 2$ genes in the Japanese population.

Keywords Single-nucleotide polymorphism (SNP) · Breast cancer susceptibility gene $B R C A 1 \cdot B R C A 2$. Japanese population $\cdot$ Direct DNA sequencing

\section{Introduction}

Mutations in the BRCA1 and the BRCA2 genes have been linked with the susceptibility to breast and ovarian cancer (Miki et al. 1994; Wooster et al. 1995; Tavtigian et al. 1996). Mutation carriers of these genes are at high risk of breast and ovarian cancer (Narod et al. 1995; Ford et al. 1998; Thorlacius et al. 1998; Neuhausen 1999; Rebbeck 1999; Struewing et al. 1997; Anglian Breast Cancer Study Group 2000). The two genes have large coding sequences consisting of 48 exons in total, and a large number of mutations and SNPs are reported in the Breast Cancer Information Core (BIC) database (http:// research.nhgri.nih.gov/bic/) and the dbSNP database (http://www.ncbi.nlm.nih.gov/SNP/index.html). The majority of mutations described are protein-truncating mutations containing frame-shift mutations and nonsense mutations. In the BIC database, $55.9 \%$ of genetic variants are reported as pathogenic mutations containing mainly protein-truncating mutations and a small fraction of pathogenic missense mutations, and $39.3 \%$ of variants are categorized as "unclassified variants." These variants contain coding SNPs (cSNPs) that result in amino-acid substitutions or SNPs located at exon-intron boundaries. We have also reported five protein-truncating mutations and 12 "unclassified variants" that have been found only once in 24 breast cancer families (Sakayori et al. 2003). To elucidate whether detected SNPs are pathogenic mutations or not, it is important to accumulate SNP information (both the type and allele frequency) in patients and the general population. 
Table 1 Sequence variations detected in the $B R C A 1$ and the $B R C A 2$ genes

\begin{tabular}{|c|c|c|c|c|c|c|}
\hline SNP ID ${ }^{\mathrm{a}}$ & Location & Variation $^{\mathrm{b}}$ & Flanking sequence $\left(5^{\prime}\right.$ to $\left.3^{\prime}\right)$ & $\mathrm{dbSNP}_{\mathrm{ID}}^{\mathrm{c}}$ & $\mathrm{BIC}^{\mathrm{d}}$ & Volunteers $^{\mathrm{e}}$ \\
\hline \multicolumn{7}{|l|}{$B R C A$ lgene } \\
\hline BRCA1-1 & Intron 1 & IVS1-115C > T & tggtttgtat $\mathrm{C} / \mathrm{T}$ attctaaaac & rs3765640 & & + \\
\hline BRCA1-3 & Intron 8 & IVS8-58delT & tacatttttt $\mathrm{T} /-$ aaccetttta & & + & + \\
\hline BRCA1-4 ${ }^{\#}$ & Exon 11 & G275D $(824 G>A)$ & gagccatgtg $\mathrm{G} /$ A cacaaatact & & & \\
\hline BRCA1-5 & Exon 11 & S694 (silent) $(2082 \mathrm{C}>\mathrm{T})$ & gacatgacag $\mathrm{C} / \mathrm{T}$ gatactttcc & rs1799949 & + & + \\
\hline BRCA1-6 & Exon 11 & L771 (silent) $(2311 \mathrm{~T}>\mathrm{C})$ & cagtatttca $\mathrm{T} / \mathrm{C}$ tggtacctgg & rs16940 & + & + \\
\hline BRCA1-9 & Exon 11 & E1038G $(3113 A>G)$ & gtttttaaag $\mathrm{A} / \mathrm{G}$ agccagctca & rs16941 & + & + \\
\hline BRCA1-10 & Exon 11 & K1183R $(3548 A>G)$ & agcgtccaga $\mathrm{A} / \mathrm{G}$ aggagagctt & rs16942 & + & + \\
\hline BRCA1-11 \# & Exon 12 & $\mathrm{C} 1372 \mathrm{X}(4116 \mathrm{~T}>\mathrm{A})^{*}$ & catctgggtg $\mathrm{T} / \mathrm{A}$ gagagtgaaa & & & \\
\hline BRCA1-12 & Exon 13 & S1436 (silent) $(4308 \mathrm{~T}>\mathrm{C})$ & taagtgactc $\mathrm{T} / \mathrm{C}$ tetgecettg & rs1060915 & + & + \\
\hline BRCA1-13 $\#$ & Intron 14 & $\mathrm{IVS} 14+14 \mathrm{~A}>\mathrm{G}$ & agaaacatca $\mathrm{A} / \mathrm{G}$ tgtaaagatg & & + & \\
\hline BRCA1-14 & Exon 16 & $\mathrm{~S} 1613 \mathrm{G}(4837 \mathrm{~A}>\mathrm{G})$ & atctgcccag $\mathrm{A} / \mathrm{G}$ gtccagctgc & rs1799966 & + & + \\
\hline BRCA1-20 & Exon 3 & $\mathrm{H} 41 \mathrm{R}(122 \mathrm{~A}>\mathrm{G})$ & aagtgtgacc $\mathrm{A} / \mathrm{G}$ catatttgcaaa & & & \\
\hline BRCA1-21 & Exon 8 & 470-471delCT* & tccaactct $\mathrm{CT} /-$ aaccttggaa & & + & \\
\hline \multicolumn{7}{|l|}{$B R C A 2$ gene } \\
\hline BRCA2-1 & Exon 2 & $5^{\prime} \mathrm{UTR}-26 \mathrm{G}>\mathrm{A}$ & tatttaccaa $\mathrm{G} / \mathrm{A}$ cattggagga & rs1799943 & + & + \\
\hline BRCA2-2 $2^{\#}$ & Intron 2 & IVS2-16T > A & taaggtggga $\mathrm{T} / \mathrm{A}$ ttttttttta & & & \\
\hline BRCA2-3 $3^{\#}$ & Intron 2 & IVS2-9T $>$ G & ggatttttt $\mathrm{T} / \mathrm{G}$ ttaaatagat & & & \\
\hline BRCA2-4 & Intron 4 & IVS4 $+67 \mathrm{~A}>\mathrm{C}$ & tgttctataa $\mathrm{A} / \mathrm{C}$ gatgaatctg & & & + \\
\hline BRCA2-5 & Intron 4 & IVS4-89T >C & acaatttata $\mathrm{T} / \mathrm{C}$ gaatgagaat & & + & + \\
\hline BRCA2-6 & Intron 7 & IVS7 $+183 \mathrm{~T}>\mathrm{A}$ & caaatacatt $\mathrm{T} / \mathrm{A}$ agtggtagtc & & & + \\
\hline BRCA2-7 & Intron 8 & IVS8 + 56C > T & tttggaatgc $\mathrm{C} / \mathrm{T}$ ttgttaaatt & & + & + \\
\hline BRCA2-8 & Exon 10 & F266 (silent) $(798 \mathrm{~T}>\mathrm{C})$ & gtcatggatt $\mathrm{T} / \mathrm{C}$ ggaaaaacat & & & \\
\hline BRCA2-9 & Exon 10 & $\mathrm{~N} 289 \mathrm{H}(865 \mathrm{~A}>\mathrm{C})$ & gtcaatgcca $\mathrm{A} / \mathrm{C}$ atgtcctaga & rs766173 & + & + \\
\hline BRCA2-10 & Exon 10 & H372 N $(1114 C>A)$ & aaatgtagca $\mathrm{C} / \mathrm{A}$ atcagaagcc & rs 144848 & + & + \\
\hline BRCA2-20\# & Exon 11 & G2044V $(6131 \mathrm{G}>\mathrm{T})$ & tcccaaaaag $\mathrm{G} / \mathrm{T}$ cttttcatat & & + & + \\
\hline BRCA2-21 & Exon 14 & S2414 (silent) $(7242 \mathrm{~A}>\mathrm{G})$ & aaactaaatc $\mathrm{A} / \mathrm{G}$ cattttcaca & Rs1799955 & + & + \\
\hline BRCA2-22 \# & Exon 11 & 6491-6495delAGTTG* & gacaaacaac AGTTG/- gtattaggaa & & & \\
\hline BRCA2-23 & Intron 16 & $\mathrm{IVS} 16+47 \mathrm{~A}>\mathrm{G}$ & gtattccetc $\mathrm{A} / \mathrm{G}$ tccetctttc & & & \\
\hline BRCA2-24 & Intron 16 & IVS16-14T > C & aatattctac $\mathrm{T} / \mathrm{C}$ tttatttgtt & & + & + \\
\hline BRCA2-25 & Exon 11 & V2109I (6325G＞A) & acttcctcgt $\mathrm{G} / \mathrm{A}$ ttgataagag & & + & \\
\hline BRCA2-26\# & Exon 20 & $\mathrm{~S} 2835 \mathrm{X}(8504 \mathrm{C}>\mathrm{A})^{*}$ & gagaagacat $\mathrm{C} / \mathrm{A}$ atctggatta & & & \\
\hline BRCA2-27 & Intron 22 & IVS22-147A > G & cagataaagt $\mathrm{A} / \mathrm{G}$ taaagttagt & & & \\
\hline BRCA2-28 & Exon 25 & $\mathrm{R} 3128 \mathrm{X}(9382 \mathrm{C}>\mathrm{T}) *$ & AacctccagtggC/Tgaccagaatcc & & + & \\
\hline BRCA2-29 & Exon 10 & $1278 \operatorname{delA}^{*}$ & ttcagaaaa $\mathrm{A} /$ - gacctattag & & & \\
\hline BRCA2-30 & Exon 10 & K322Q $(964 A>C)$ & aaatctacaa $\mathrm{A} / \mathrm{C}$ aagtaagaactagc & & + & \\
\hline BRCA2-31 & Exon 10 & E425 (silent) $(1275 \mathrm{~A}>\mathrm{G})$ & aaatatttcaga $\mathrm{A} / \mathrm{G}$ aaagacct & & & \\
\hline BRCA2-32 & Exon 11 & V1269 (silent) $(3807 \mathrm{~T}>\mathrm{C})$ & catgattctgt $\mathrm{T} / \mathrm{C}$ gtttcaatgt & & + & \\
\hline BRCA2-33 & Exon 11 & E1455 (silent) $(4365 A>G)$ & cagaaaccaga A/G gaattgcata & & & \\
\hline BRCA2-34 & Exon 18 & $\mathrm{~K} 2729 \mathrm{~N}(8187 \mathrm{G}>\mathrm{T})$ & tatgctgttaa $\mathrm{G} / \mathrm{T}$ geccagttagatcct & & + & \\
\hline
\end{tabular}

${ }^{a}$ The SNP ID that have been found in this study. " Published previously (Sakayori et al. 2003)

${ }^{\mathrm{b}}$ The nucleotide number in the coding region indicates the position downstream of the first nucleotide of ATG (initiation codon) in the $B R C A 1$ gene or the BRCA2 gene. *: Nonsense or frame-shift mutation
${ }^{\mathrm{c}}$ National Center for Biotechnology Information (NCBI) dbSNP database

${ }^{\mathrm{d} B r e a s t}$ Cancer Information Core (BIC) database, + : listed in BIC e 28 Japanese healthy volunteers, + : found at least one individual 
Table 2 Allele frequencies of SNPs in the BRCAl and the $B R C A 2$ genes adentical to the SNP ID listed in Table $1,{ }^{\#}$ : found in a relative but not in the proband ${ }^{\mathrm{b}} 110$ alleles from 55 patients, * data derived from 68 alleles (34 patients)

'56 alleles from 28 healthy volunteers, ND: not determined

${ }^{\mathrm{d}}$ National Center for Biotechnology Information (NCBI) dbSNP database

\begin{tabular}{|c|c|c|c|}
\hline \multirow[t]{2}{*}{ SNP ID ${ }^{a}$} & \multicolumn{3}{|l|}{ Allele frequency } \\
\hline & Breast cancer patients ${ }^{b}$ & Volunteers $^{\mathrm{c}}$ & $\mathrm{dbSNP}^{\mathrm{d}}$ \\
\hline \multicolumn{4}{|l|}{$B R C A$ lgene } \\
\hline BRCA1-1 & $C=0.43, T=0.57$ & $C=0.52, T=0.48$ & $C=0.343, T=0.657$ \\
\hline BRCA1-2 & $G=0.93, A=0.07$ & $G=0.98, A=0.02$ & $G=0.994, A=0.006$ \\
\hline BRCA1-3 & $T 7=0.65, T 6=0.35^{*}$ & $T 7=0.50, T 6=0.50$ & \\
\hline BRCA1-4 & $G=0.98, A=0.02$ & $G=1.00, A=0.00$ & \\
\hline BRCA1-5 & $C=0.62, T=0.38$ & $C=0.56, T=0.44$ & $C=0.657, T=0.343$ \\
\hline BRCA1-6 & $T=0.62, C=0.38$ & $T=0.54, C=0.46$ & $T=0.678, C=0.322$ \\
\hline BRCA1-8 & $C=0.62, T=0.38$ & $C=0.54, T=0.46$ & $C=0.619, T=0.381$ \\
\hline BRCA1-9 & $A=0.62, G=0.38$ & $A=0.54, G=0.46$ & $A=0.725, G=0.275$ \\
\hline BRCA1-10 & $A=0.62, G=0.38$ & $A=0.54, G=0.46$ & $A=0.703, G=0.297$ \\
\hline BRCA1-12 & $T=0.62, C=0.38$ & $T=0.54, C=0.46$ & $T=0.747, C=0.253$ \\
\hline BRCA1-13 & $A=0.98, G=0.02^{*}$ & $A=1.00, G=0.00$ & \\
\hline BRCA1-14 & $A=0.62, G=0.38$ & $A=0.54, G=0.46$ & $A=0.696, G=0.304$ \\
\hline BRCA1-15 & $T=0.98, C=0.02$ & $T=1.00, C=0.00$ & $T=0.995, C=0.005$ \\
\hline BRCA1-16 & $G=0.63, A=0.37$ & $G=0.54, A=0.46$ & $G=0.693, A=0.307$ \\
\hline BRCA1-17 & $A=0.98, G=0.02 *$ & $A=1.00, G=0.00$ & \\
\hline BRCA1-18 & $G=0.99, T=0.01$ & $G=1.00, T=0.00$ & \\
\hline BRCA1-20 & $A=0.99, G=0.01$ & ND & \\
\hline \multicolumn{4}{|l|}{$B R C A 2$ gene } \\
\hline BRCA2-1 & $G=0.55, A=0.45$ & $G=0.49, A=0.51$ & $G=0.762, A=0.238$ \\
\hline BRCA2-2 & $T=0.97, C=0.03^{*}$ & $T=1.00, C=0.00$ & \\
\hline BRCA2-3 & $T=0.98, G=0.02 *$ & $T=1.00, C=0.00$ & \\
\hline BRCA2-4 & $A=0.84, C=0.16^{*}$ & $A=0.84, C=0.16$ & \\
\hline BRCA2-5 & $T=0.84, C=0.16^{*}$ & $T=0.84, C=0.16$ & \\
\hline BRCA2-6 & $T=0.32, A=0.68^{*}$ & $T=0.58, A=0.42$ & \\
\hline BRCA2-7 & $C=0.96, T=0.04^{*}$ & $C=0.96, T=0.04$ & \\
\hline BRCA2-8 & $T=0.98, C=0.02$ & $T=1.00, C=0.00$ & \\
\hline BRCA2-9 & $A=0.86, C=0.14$ & $A=0.84, C=0.16$ & $A=0.838, C=0.024, G=0.009, T=0.129$ \\
\hline BRCA2-10 & $A=0.80, C=0.20$ & $A=0.82, C=0.18$ & $A=0.607, C=0.281, G=0.026, T=0.085$ \\
\hline BRCA2-11 & $A=0.86, G=0.14$ & $A=0.84, G=0.16$ & $A=0.875, G=0.125$ \\
\hline BRCA2-12 & $A=0.99, C=0.01$ & $A=1.00, C=0.00$ & \\
\hline BRCA2-13 & $T=0.86, C=0.14$ & $T=0.84, C=0.16$ & \\
\hline BRCA2-14 & $A=0.93, G=0.07$ & $A=0.95, G=0.05$ & \\
\hline BRCA2-15 & $A=0.85, G=0.15$ & $A=0.84, G=0.16$ & $A=0.970, G=0.030$ \\
\hline BRCA2-16 & $A=0.47, G=0.53$ & $A=0.50, G=0.50$ & $A=0.705, G=0.295$ \\
\hline BRCA2-17 & $T=0.99, C=0.01$ & $T=1.00, C=0.00$ & \\
\hline BRCA2-19 & $G=0.98, T=0.02$ & $G=1.00, T=0.00$ & \\
\hline BRCA2-20 & $G=0.97, T=0.03$ & $G=0.98, T=0.02$ & \\
\hline BRCA2-21 & $A=0.58, G=0.42$ & $A=0.50, G=0.50$ & $A=0.758, G=0.242$ \\
\hline BRCA2-23 & $A=0.96, G=0.04^{*}$ & $A=1.00, G=0.00$ & \\
\hline BRCA2-24 & $T=0.36, C=0.64$ & $T=0.27, C=0.73$ & \\
\hline BRCA2-25 \# & $G=0.99, A=0.01$ & $G=1.00, A=0.00$ & \\
\hline BRCA2-27 \# & $A=0.98, G=0.02 *$ & $A=1.00, G=0.00$ & \\
\hline BRCA2-30 & $A=0.97, C=0.03$ & ND & \\
\hline BRCA2-31 & $A=0.97, C=0.03$ & ND & \\
\hline BRCA2-32 & $T=0.86, C=0.14$ & ND & \\
\hline BRCA2-33 & $A=0.98, G=0.02^{*}$ & ND & \\
\hline BRCA2-34 & $G=0.98, T=0.02$ & ND & \\
\hline
\end{tabular}

In this study, we extended our study on the $B R C A 1$ and $B R C A 2$ sequencing project to 55 breast cancer patients from 50 Japanese breast cancer families. We evaluated the detected SNPs by comparing the allele frequency of the SNPs in healthy volunteers.

\section{Subjects and methods}

Fifty-five enrolled patients (including 50 probands and five relatives) with a history of breast cancer from 50 unrelated high-risk breast cancer families were selected according to the criteria defined by the Tohoku Familial Cancer Society (Sakayori et al. 2003). An additional 28
Japanese volunteers with no breast cancer family history were also enrolled to analyze the specific $B R C A 1$ and $B R C A 2$ variations detected in the breast cancer patients. We obtained informed consent from all patients and volunteers, and the independent studies were approved by the Familial Cancer Society and the Ethical Committee of Tohoku University Graduate School of Medicine. To identify the sequence variations in the $B R C A 1$ and $B R C A 2$ genes of the familial breast cancer patients, we sequenced approximately $23 \mathrm{~kb}$ genomic regions of the $B R C A 1(8.4 \mathrm{~kb})$ and the $B R C A 2(14.6 \mathrm{~kb})$ containing all coding exons and their franking introns using a method described previously (Sakayori et al. 2003). The identified SNPs found in the familial breast cancer 
patients were also examined in the genomic DNA from the healthy volunteers by PCR-RFLP analysis using PCR primers, cycle conditions and restriction enzymes for PCR-RFLP analysis (http://www.idac.tohoku.ac.jp/ dep/co/data/saka/brca02.htm) or by DNA sequence analysis. We used Genbank (U14680 and U61268 for $B R C A 1$, U43746 and X95152-77 for BRCA2) and the $\mathrm{BIC}$ database as the reference sequences of $B R C A 1$ and $B R C A 2$ genes.

\section{Results and discussion}

By DNA sequencing analysis of the BRCAl and $B R C A 2$ genes for 55 patients from 50 unrelated breast cancer families; we detected 55 SNPs (21 SNPs in $B R C A 1$ and 34 SNPs in BRCA2). Among these SNPs, we found nine protein-truncating mutations (four in $B R C A$ land five in $B R C A 2$ ) in ten patients containing six novel mutations that were not found in the BIC database (http://research.nhgri.nih.gov/bic/) (Table 1). The existence of mutations were also confirmed by the stop codon assay in yeast (Ishioka et al. 1997; Sakayori et al. 2003). The percentage of protein-truncating mutations in the examined families was $20 \%$ (ten of 50), comparable with several reports describing the frequency of protein-truncating mutations of the two genes in Japanese breast cancer families (Inoue et al. 1995; Takano et al. 1997; Inoue et al. 1997; Ikeda et al. 2001). Although the frequency was also similar to results from Western populations, the number of patients studied in our and other Japanese populations was smaller than that in Western countries. Therefore, it is necessary to study a larger number of patients to clarify the mutation frequency in Japanese familial breast cancer.

Among the remaining 46 SNPs (17 SNPs in BRCA1 and 29 SNPs in $B R C A 2$ ), 18 and 31 have been reported in the dbSNP database and in the BIC database, respectively, (Table 1). To evaluate whether the SNPs are also found in Japanese healthy volunteers, all but six SNPs were further examined by PCR-RFLP analysis or by DNA sequence analysis. Twenty-six SNPs were found in the volunteers at least once with different allele frequencies (Table 2). In these $40 \mathrm{SNPs}$, we predicted that 27 SNPs were common polymorphisms and probably played no direct role in the tumorigenesis of breast cancer. The remaining 13 SNPs were quite low in allele frequency $(<0.05)$ and were not found in the healthy volunteers or the dbSNP database. In addition, there were six SNPs that failed to examine in the volunteer group. In these six SNPs, one was predicted to be common and five to be rare from the allele frequencies in the patients. Overall, we predicted the 18 rare SNPs are candidates of pathogenic mutations and that the remaining 28 were common polymorphisms and probably have no direct roll in tumorigenesis of breast cancer. In the 18 rare SNPs, five (BRCA1-13, BRCA1-17, BRCA1-18, BRCA2-2, BRCA2-3) were located at the exon-intron boundaries and two (BRCA2-23, BRCA2-
27) were located in introns far from exon-intron boundaries. Although SNPs at the exon-intron boundaries may affect normal RNA splicing, our RT-PCR analysis showed negative data for splicing abnormalities. In the remaining 11 rare cSNPs, seven (BRCA1-4, BRCA1-20, BRCA2-12, BRCA2-19, BRCA2-25, BRCA2-30 and BRCA2-34) were nonsynonymous substitution resulting in the amino-acid substitutions, and four (BRCA2-8, BRCA2-17, BRCA2-31 and BRCA233) were synonymous (silent) changes. These SNPs may directly affect the functions of BRCA1 and BRCA2 proteins or affect normal splicing by acting as possible cryptic splicing sites. Unfortunately, we have failed to clarify this issue mainly because there are no reliable functional assays of either BRCA1 or BRCA2 protein for many nonsynonymous changes.

To confirm the pathogenic effect of rare SNPs, both the development of functional assays for these gene products and more intensive SNP analysis including an investigation into whether these SNPs cosegregate with breast cancer onset in families are necessary.

Acknowledgements We thank patients and their families for participating in this study. We also thank Yuka Fujimaki for technical assistance. This study was supported in part by a grant from the Ministry of Education, Science, Sports and Culture of Japan.

\section{References}

Anglian Breast Cancer Study Group (2000) Prevalence and penetrance of BRCA1 and BRCA2 mutations in a population-based series of breast cancer cases. Br J Cancer 83:1301-1308

Ford D, Easton DF, Stratton M, Narod S, Goldgar D, Devilee P, Bishop DT, Weber B, Lenoir G, Chang-Claude J, Sobol H, Teare MD, Struewing J, Arason A, Scherneck S, Peto J, Rebbeck TR, Tonin P, Neuhausen S, Barkardottir R, Eyfjord J, Lynch H, Ponder BA, Gayther SA, Zelada-Hedman M et al (1998) Genetic heterogeneity and penetrance analysis of the $B R C A 1$ and $B R C A 2$ genes in breast cancer families. The breast cancer linkage consortium. Am J Hum Genet 62:676-689

Ikeda N, Miyoshi Y, Yoneda K, Shiba E, Sekihara Y, Kinoshita M, Noguchi S (2001) Frequency of BRCA1 and BRCA2 germline mutations in Japanese breast cancer families. Int $\mathbf{J}$ Cancer 91:83-88

Inoue R, Fukutomi T, Ushijima T, Matsumoto Y, Sugimura T, Nagao M (1995) Germline mutation of BRCA1 in Japanese breast cancer families. Cancer Res 55:3521-3524

Inoue R, Ushijima T, Fukutomi T, Fukami A, Sugimura H, Inoue S, Okonogi H, Sugimura T, Matsumoto Y, Nagao M (1997) BRCA2 germline mutations in Japanese breast cancer families. Int J Cancer 74:199-204

Ishioka C, Suzuki T, FitzGerald M, Krainer M, Shimodaira H, Shimada A, Nomizu T, Isselbacher KJ, Haber D, Kanamaru R (1997) Detection of heterozygous truncating mutations in the BRCA1 and APC genes by using a rapid screening assay in yeast. Proc Natl Acad Sci USA 94:2449-2453

Miki Y, Swensen J, Shattuck-Eidens D, Futreal PA, Harshman K, Tavtigian S, Liu Q, Cochran C, Bennett LM, Ding W and others (1994) A strong candidate for the breast and ovarian cancer susceptibility gene BRCA1. Science 266:66-71

Narod SA, Ford D, Devilee P, Barkardottir RB, Lynch HT, Smith SA, Ponder BA, Weber BL, Garber JE, Birch JM and others (1995) An evaluation of genetic heterogeneity in 145 breastovarian cancer families. Breast cancer linkage consortium. Am J Hum Genet 56:254-264 
Neuhausen SL (1999) Ethnic differences in cancer risk resulting from genetic variation. Cancer 86:2575-2582

Rebbeck TR (1999) Inherited genetic predisposition in breast cancer. A population-based perspective. Cancer 86:2493-2501

Sakayori M, Kawahara M, Shiraishi K, Nomizu T, Shimada A, Kudo T, Abe R, Ohuchi N, Takenoshita S, Kanamaru R, Ishioka C (2003) Evaluation of the diagnostic accuracy of the stop codon (SC) assay for identifying protein-truncating mutations in the BRCA1 and BRCA2 genes in familial breast cancer. J Hum Genet 48:130-137

Struewing JP, Hartge P, Wacholder S, Baker SM, Berlin M, McAdams M, Timmerman MM, Brody LC, Tucker MA (1997) The risk of cancer associated with specific mutations of BRCA1 and BRCA2 among Ashkenazi Jews. N Engl J Med 336:14011408

Takano M, Aida H, Tsuneki I, Takakuwa K, Hasegawa I, Tanaka H, Saito M, Tsuji S, Sonoda T, Hatae M, Chen JT, Takahashi K, Hasegawa K, Toyoda N, Saito N, Yakushiji M, Araki T,
Tanaka K (1997) Mutational analysis of BRCA1 gene in ovarian and breast-ovarian cancer families in Japan. Jpn $\mathbf{J}$ Cancer Res 88:407-413

Tavtigian SV, Simard J, Rommens J, Couch F, Shattuck-Eidens D, Neuhausen S, Merajver S, Thorlacius S, Offit K, StoppaLyonnet D, Belanger C, Bell R, Berry S, Bogden R, Chen Q, Davis $T$, Dumont $M$, Frye $C$, Hattier $T$, Jammulapati $S$, Janecki T, Jiang P, Kehrer R, Leblanc JF, Goldgar DE et al. (1996) The complete BRCA2 gene and mutations in chromosome 13q-linked kindreds. Nat Genet 12:333-337

Thorlacius S, Struewing JP, Hartge P, Olafsdottir GH, Sigvaldason $\mathrm{H}$, Tryggvadottir L, Wacholder S, Tulinius H, Eyfjord JE (1998) Population-based study of risk of breast cancer in carriers of BRCA2 mutation. Lancet 352:1337-1339

Wooster R, Bignell G, Lancaster J, Swift S, Seal S, Mangion J, Collins N, Gregory S, Gumbs C, Micklem G (1995) Identification of the breast cancer susceptibility gene BRCA2. Nature 378:789-792 